look upon this as a warlike demonstration, and their love of independence would then prevent the exploring party from accomplishing its task.

Not only from a geographical and ethnological point of view is this expedition expected to be a brilliant success, but also in the several departments of natural history the results are likely to be of high scientific value. A naturalist is to be appointed, who will accompany the explorers and enrich the zoological and geological departments of the national museum of Holland with interesting specimens from regions hitherto so superficially known.

There is some probability of a botanist being appointed by a committee of botanists and horticulturists, who will pay his expenses, and thus make the expedition profitable for this department of natural science as well.

The staff of the expedition will further consist of an able geographer, to whom the topographical department is to be confided, and of a linguist; who will study the languages of the tribes met with. It is a curious fact that in Sumatra the languages spoken by contiguous populations show very considerable differences. He will at the same time be able to serve as an interpreter, where this may prove necessary, and will no doubt have occasion to gather some interesting ethnological data. An artist will complete the party of explorers, which is to leave Holland in the beginning of next summer.

It is expected that one or more able naval officers will be appointed by the Indian Government to the command of the vessel in which a great part of the surveying work is to be done. They will of course bring a most welcome support to the geographer, to whom assistance of this kind may prove almost indispensable.

As to the financial side of the question, the expenses required to carry out the scheme when reduced to its most simple dimensions, have been evaluated at 2,000 guineas. The Geographical Society, having been founded only a couple of years ago, has no funds at all at its disposal, and so an appeal has been made to the public, scientific and commercial, with a view of obtaining the required money by private efforts only. Government will not be applied to before the subscriptions have surpassed the above sum, and when the possibility of realisation will thus have been assured. A Governmental subsidy will then not be a conditio sine quâ non for the expedition, but only a means of giving it a wider extension, of bringing within its range a larger field than the original 2,000 guineas would admit of. As the national interest in the expedition is increasing every day, it is expected that this sum will be raised within a very short time.

The Colonial Office at the Hague strongly supports the efforts of the Society, and the Government at Batavia has promised its earnest co-operation. Another favourable circumstance is to be found in the willingness of the Sultan of Djambi, now on the best terms with the Dutch colonial authorities, first, to permit of this scientific invasion into his domains, and secondly, to lend his assistance wherever this might be of any use. As a palpable proof he has already put his son-in-law at the disposal of the exploring party, for the purpose of accompanying them on their tours. Policy seems to play a part in the unexpected magnanimity of this potentate.

Let us hope the best for the realisation of all those promising plans, and may I, ere long, have the opportunity of bringing under your notice some results of an expedition by which science in general cannot but profit.

\section{A. A. W. HUBRECHT}

FERTILISATION OF FLOWERS BY INSECTS* XII.-Further Observations on Alpine Flowers.

I AST year, after having spent my vacation in the observation of Alpine flowers and their fertilisation by insects, I nublished some articles in this journal, in Contimed from vol xii p. xor. order to show that, in the Alpine region, Lepidoptera are far more frequent visitors of flowers than in the plain and in the lower mountainous region, while the frequency of Apidæ, not only absolutely but to a still greater extent relatively, greatly diminishes towards the snow line (see NATURE, vol. xi. pp. 32, Iro, and 169). Further, in these articles I attempted to demonstrate that some Alpine species (Daphne striata, Primula villosa, Khinanthus alpinus) are adapted to cross-fertilisation by butterflies, whilst the most nearly-allied species which inhabit the plain or lower mountain region (Daphne Mezereum, Primula officinalis, Rhinanthus crista-galli) are cross-

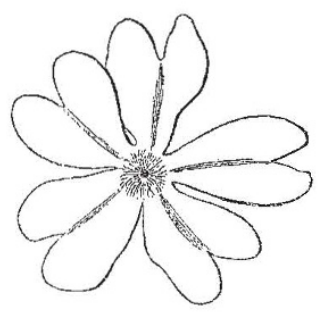

Fig. 71.

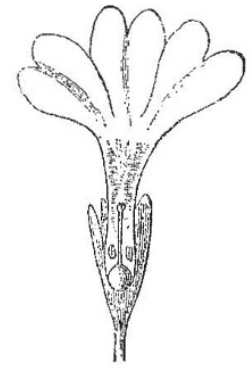

FIG. 72. fertilised by bees; and that among the family of Orchids, by far the majority of species growing in Alpine regions are likewise adapted to Lepidoptera.

Last summer having revisited the Alps, in this and following articles I intend to show how far the results arrived at by my first excursion are confirmed, completed, or modified by my new observations.

Firstly, I will give some additional notes concerning the species treated of in my previous articles.

I. With regard to the fertilisation of Daphne Mezereum and striata, I concluded, solely from the length and width of the corolla-tubes, and from their colour and scent, that the former were adapted to cross-fertilisation by bees and some flies, the latter by Sphingidæe and moths; but direct observation of the fertilisers was wanting. Last sprino, April I4th, in the valley of Poeppelsche, near Lippstadt, watching the flowers of $D$. Mezereum in calm and sunny weather, I succeeded in confirming my previous conclusions, so far as D. Merereum is concerned, by

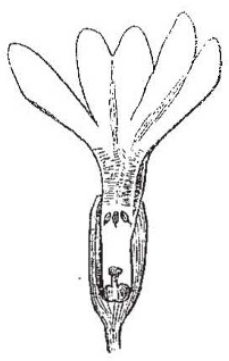

FIG. 73 .

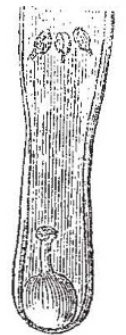

FIG. 74.

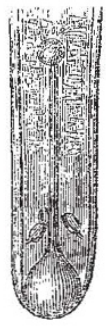

FIG. 75. direct observation. Some humble-bees which escaped to my net, several specimens of the hive-bee, and single specimens of Anthophora pilipes, F., ô, Osmia fusca, Chr., $t$, and Osmia rufa, L., $\delta$, were perseveringly occupied in inserting their proboscides into the base of the corolla, apparently sucking its honey, whilst many smaller bees (Halictus cylinaricus, F., P, H. leucopus, $K ., P, H$. nitidus, Schenck, $P$, and $H$. minutissimus, $\mathrm{K}$., P) were crawling with their whole bodies into the corollas, partly in order to suck the honey, partly collecting the pollen. Some Muscidæ also visited the flowers, touching stigma, anthers, and different other parts, with the flaps of their fleshy mouth, and sucking the honey. Besides these Apirla and Diptera, only one butterlly 
(Vanessa Urtice) was attracted by the bright colour of the flowers, and inserted its proboscis into several of them, possibly without touching stigma and anthers.

of Daphne striata I had not yet the opportunity of observing the fertilisers; but completely white flowers of this species, which I found in the pass of Strela, near Davos, may be considered as confirming my supposition that $D$. striata is adapted to crespuscular and nocturnal Lepidoptera.

2. Regarding Primula officinalis and villosa, no additional remarks are to be made. I have, however, observed another Alpine species* of Primula (P. integrifolia), which

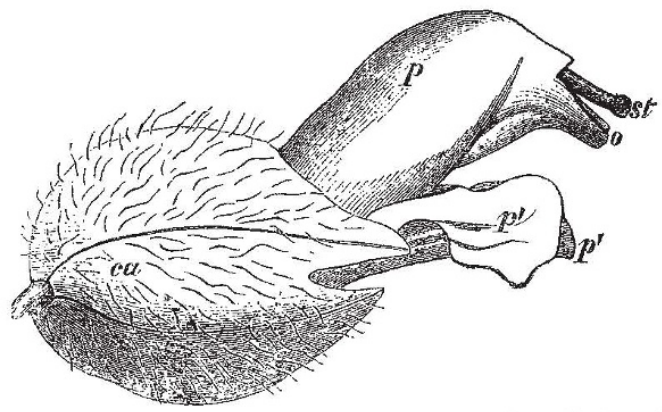

FıGS. 76-8r. Rhinanthus alectorolophus.* FIG. 76.--Lateral view of the flower.

is apparently adapted, like $P$. villosa, by the narrowness of the entrance of its corolla-tube, to butterflies. And with regard to some other species which inhabit higher Alpine localities ( $P$. longiflora, and $P$. minima) I suppose that they are in the same condition, Primula integrifolic, which I found frequently on the summits surrounding the passes of Streia and Fluela, is dimorphic, like most other species of this genus. Its sexual organs are quite included, the stioma of the long-styled and the anthers of the short-styled form occupying nearly the centre, the anthers of the long-styled and the stigma of the short-styled form occupying the lower part ( $1 \frac{1}{2} \mathrm{~mm}$. above the ovary and $3 \mathrm{~mm}$. above the ground) of the corolla-tubes. (Compare Figs. 72 and 73, 74 and 75.) Honey is secreted by the ovary in such quantity that it fills up the lowermost part of the corolla-tube so far as nearly to reach the stigma of the short-styled and the anthers of the long-styled form. The corolla-tube being $10-17 \mathrm{~mm}$. long and about $2 \mathrm{~mm}$. wide, its dimensions would allow

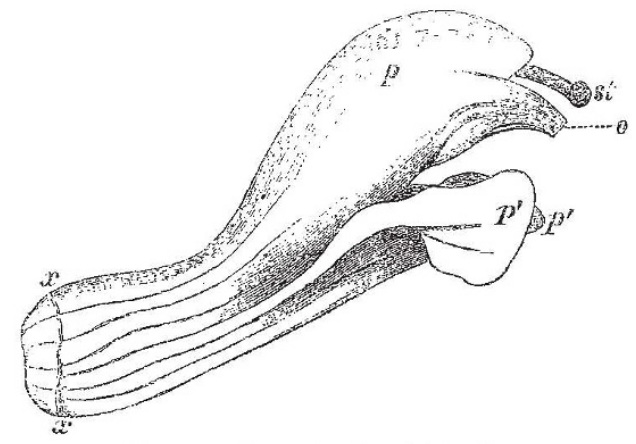

FiG. 77. -The corolla viewed laterally.

humble-bees also access to the honey; but the entrance to the corolla being contracted to $\mathrm{I} \mathrm{mm}$. (Fig. 7I), no other insect but a lepidopterous one would be enabled

* All the figures are $3 \frac{1}{2}$ times natural size. In all figures : ca, calyx ; ppp, upper petals, forming together the upper lip: $\not \not^{\prime} p^{\prime} p^{\prime}$, lower petals, forming the lower lip; $a^{x}$, longer stamens ; $a^{2}$, shorter stamens; 2 , nectary; ov ovary; st, stigma ; e, usual entrance for the humble-bees; 0 , minute opening for the butterflies. The dotted line in Fig. 80 indicates the path of the proboscis of sucking humble-bees; the dotted line in Fig. $8 x$ the path of the
proboscis of butterflies. to insert its proboscis into the base of the flower and reach the honey. On the other hand, the corolla is narrow enough to force also the thin proboscis of a butterfly to touch, when inserted, both the stigma and the anthers. I do not doubt, therefore, that $P$. integrifolia is also crossfertilised by butterflies, although, from the unfavourable state of the weather, I have had no opportunity of observing its fertilisers.

3. Rhinanthus alpinus last year attracted my attention only during the last days of my stay in the Alps, when rainy weather prevented me from observing its fertilisers ;

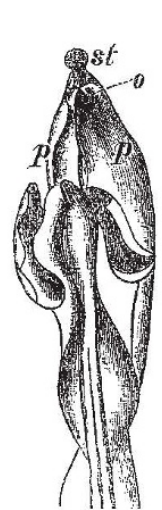

Fig. 78.

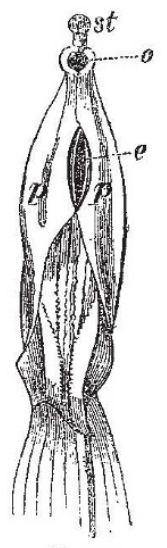

Fig. 79 .

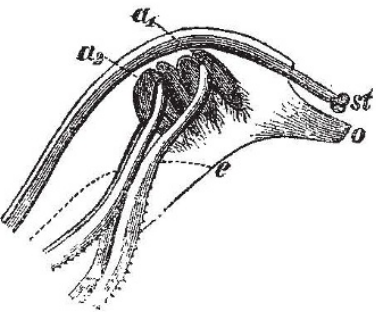

FIG. 80.
FIG. 78.-Front view of the upper part of the corolla. FiG. 79. - The same with the under lip removed. FIG. 80. - The upper part of the corolla, longitudinally dissected, but all four anthers reversed.

I concluded, solely from the structure of its flowers, that it was adapted to butterflies. This year it was an object of my continued attention; and in a region where Lepidoptera are predominant, but humble-bees are also very frequent, near Tschuggen ( 1,900 to $2,000 \mathrm{~m}$. above the sea-level), Forno ( $1,800 \mathrm{~m}$.$) , Valcava (1,500 \mathrm{~m}$.$) , and St.$ Gertrud, Sulden ( 1,800 to $\mathbf{I}, 900 \mathrm{~m}$.), I had large opportunities of directly observing its fertilisation by insects. But I was greatly struck by the fact that in these localities humble-bees visit its flowers far more frequently than butterflies. The number of visits which Bombus alticola,

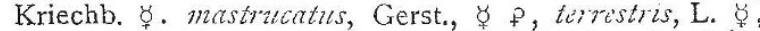
pratorum, L. $\not$, and Protens, Gerst., $\not$, in these localities make to the flowers of R/l. alpinits, is at least ten times greater than the number of visits by butterflies (Argymis

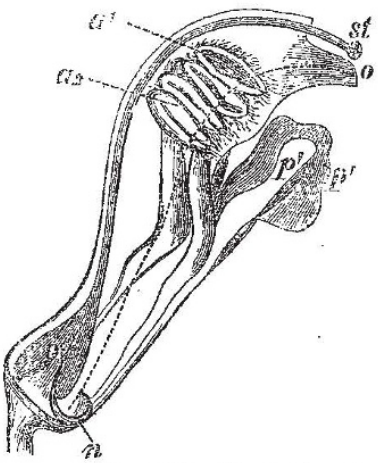

Fig. 8x - The whole corolla, dissected longitudinally.

Aglaia. L., A. ino, Rott., Lycaena alsus, W. V., L. semiargus, Rott., Larentia albulata, W.V.(?), Botys spec., Psodos quadrifaria, Sulz.), which, of course, solely search for honey. But the humble-bees treat the flowers in such a forcible manner, that by their very visits they prove that these flowers are by no means adapted to them. Alighting on the helm-shaped upper lip, the humble-bees are obliged to turn round in order to reach the face of the flower 
then, the entrance between the margins of the upper lip being completely closed, they forcibly break it open with their fore-legs, grasping with them between the margins, and shaking the anthers in order to gain their pollen; thus a good deal of the smooth, powdery pollen grains, falling out of the shaken anthers, is received within the brushes and feathery hairs of their fore-legs, and thence carried to the pollen-collecting orifice of the posterior tibiæ. This incommodious and wearisome labour, although performed by the humble-bees with admirable dexterity and perseverance, contrasts remarkably with the swift and light manner of their gathering pollen, and at the same time sucking honey in flowers adapted to them ; $*$ and many peculiarities of the flowers of $R h$ alpi. nuls would be quite unintelligible under the supposition that pollen-collecting humble-bees were the true and original fertilisers of them. The honey, so copiously secreted in the base of these flowers, would be quite useless to the plant if pollen-collecting humble-bees were its true fertilisers; the minute opening between the two lateral flaps at the tip of the beaked prolongation of the upper lip would likewise be useless, and the closeness of the usual entrance between the margins of the upper lip would be a mere embarrassment to the fertilisers. Supposed, on the contrary, that Lepidoptera are the original fertilisers of $R h$. alpintes, all these peculiarities are easily to be understood as very useful, nay, as indispensable to the plant ; for honey is the only food eagerly searched for by butterflies, and the closeness of the usual entrance, as well as the existence of the minute opening in its very place, are required in order to induce visiting butterflies to insert their proboscis in the only manner which can effect cross-fertilisation. Hence, in spite of the frequent visits of pollen-collecting humble-bees, and in spite of their probably effecting many cross-fertilisations, the flowers of Rh. alpinus are without any doubt to be considered as adapted exclusively to butterflies.

But considering the original function of the under lip as a landing-place for bees, and considering that the most nearly-allied genera, Euphrasia, Métampyrtm, Pedicularis, as well as Rhinanthus cristo-galli, are all adapted to bees, we can hardly doubt that also the ancestors of $\mathrm{K}$. alpinzs have been adapted to cross-fertilisation by bees, and the question may be started, by what connecting forms these ancestors could be transformed into the present form of $R h$. alpinus. We may confidently suppose that they retained the usual entrance for humble-bees, until the beaked prolongation of the upper lip, the minute opening at its tip, and the lateral flaps of this opening were so developed as to secure cross-fertilisam tion by butterflies.

In this respect Rzinanthus alectorolophus is of especial interest; for it represents really what by reflection we are induced to suppose once existed in the connecting forms between $R h$. alpinus and its ancestors (compare Figs. 76-8I). Rh. alectorolophus has indeed retained the usual entrance by which humble-bees may insert their proboscis in order to suck the honey $(c$, Figs. 79, 80), and may be regularly cross-fertilised by sucking humble-bees, whilst at the same time the minute opening (0, Figs. $76-$ 8I) and all those peculiarities which secure cross-fertilisation by sucking butterfiles, are developed.

From the structure of its flowers, as shown by Figs. $78-8 \mathrm{r}$, we should expect that this species would be crossfertilised as well by sucking humble-bees as by butterflies. My direct observation of the fertilisers, however, in the same localities with $R$. alpinus, shows no remarkable difference between $R h$. alectorolophus and $R h$. alpinus. Two species of butterfiles-Colias Plicomone and Pieris Napi-repeatedly inserted their thin proboscis into the minute opening at the tip of the upper lip of $k \hbar$. alectorolophus, apparently sucking honey; numerous specimens

* Compare Esculus Hippocastanum in " $\mathrm{H}$. Müller, Die Befruchtung der Blumen durch Insecten," 1 . $x 55$. of Bombus mastrucatuis, Gerst., $\Varangle+$, terrestris, I. $\not$, Proteus, Gerst, $\measuredangle$, and pratorum, L. $\measuredangle$, were occupied in collecting the pollen of $R h$. alectorolophus in quite the same manner as in $R h$. alpinzs. Only twice I saw humble-bees ( $B$. mastrucatas, Gerst., $\forall)$ sucking the honey of $R h$. alectorolophus, but not legitimately, by the entrance between the margins of the upper lip, but rapaciously; once by inserting their proboscis on the underside between calyx and corolla, and piercing the corollatube a little above its centre; another time by forcibly passing its proboscis through calyx and corolla.

Finally, it is to be noted that self-fertilisation of $R h$. alectorolophus is apparently impossible, for the stigma always projects, just as in Rh, major and alpinus; and when the corolla drops off (in the line $x x$; Fig. 77), and brings its anthers in contact with the stigma, this is already withered. HERMANN MÜlLER

\section{BEATS IN MUSIC *}

$\mathrm{NE}$ of the subjects treated of in Helmholtz's great work on Acoustics is that of "Beats." It is one of much interest, both theoretically and practically: theo* retically, because of the difficulty that attends the investigation of the phenomena, and of the discussions and misunderstandings that have taken place thereon among writers on scientific harmonics; practically, because beats might form an element of great utility in regard to certain practical operations, were it not that their nature and use are at present almost entirely unknown to practical musicians.

The history of the knowledge of beats is curious. They were mentioned as early as 1636 by Mersenne, and were afterwards noticed by Sauveur and others, but no sufficient explanation of their theory was given till the publication in 1749 of the learned work on Harmonics by the celebrated mathematician Dr. Robert Smith, Master of Trinity College, Cambridge. Dr. Youn 2 and Dr. Robison, both eminent writers on acoustics, quarrelled about Smith's work. Young said it added nothing to the knowledge of the subject, whereas Robison declared that it contained the greatest discoveries made since the days of Galileo; the fact, however, being probably that neither of them appreciated the main portions of the work at all. Chladni appears never to have studied the more difficult portion of the subject, and though he gives generally his references very freely, he does not mention Snith's name.

It was only in 1858 that Mr. De Morgan, in an able paper, published in the Cambridge Philosophical Transactions, pointed out the merit of Dr. Smith's investigation, and cleared up its learned obscurity.

Helmholtz treats the subject with his usual ability, but it is very singular that he, like Chladni, makes no allusion whatever to Smith's work, and as it is incredible that he should have passed over such a remarkable and profound theoretical investigation if he had been acquainted with it, I am inclined to believe that the book was unknown to him.

Considering the very few sources of information that exist in regard to beats, and the difficult shape in which this information is embodied, I have thought it might be useful, especially to practical musicians, to attempf to give some account of the subject in a more popular form; and in doing so I will endeavour to introduce the investigations of Smith, in combination with those of the later investigator.

There are three distinct kinds of beats, differing con siderably from each other in the nature of their causes and in the circumstances that attend them, and the confusion between them has caused much error in their

* By W. Pole, P.R.S., Mus, Doc. Oxon. 